\begin{abstract}
Роботу присвячено дослідженню перехідних тепломасообмінних процесів які відбуваноться в рідині, що оточуе газопарову бульбашку. Запропоновано метод цифрового рімення, який дозволяє розраховувати температурні поля в рідині з урахуванням фазових переходів, руху стінки бульбашки та теплообмінних процесів біля ї поверхні. Також враховано зміну теплофізичних характеристик рідини при зміні ї температури. Результати досліджень можуть застосовуватися для оптимізаціі різноманітних технологічних процесів пов'язаних з кавітачією, кипінням та утворенням газових гідратів

Ключові слова: теплофізичні характеристики газонасиченої рідини, газопаровий пухирець, теплообмін в двохфазному середовищі, фазові перетворення
\end{abstract}

Работа посвящена исследованию переходных тепломасообменных процессов в жидкости, окружающей газопаровой пузырек. Предложен метод иифрового решения, который позволяет рассчитывать температурные поля в жидкости с учетом фазовых переходов, движения стенки пузырька и теплообменных процессов возле её поверхности. Также учтено изменение теплофизических характеристик жидкости при изменении её температуры. Результаты исследований могут использоваться для оптимизации разнообразных технологических процессов, связанных с кавитацией, кипением и образованием газовых гидратов

Ключевые слова: теплофизические характеристики газонасыщенной жидкости, газопаровой пузырек, теплообмен в двухфазних средах, фазовые переходы
UDC 532.529

DOI: $10.15587 / 1729-4061.2017 .108535$

\section{A STUDY OF PHASE TRANSITION PROCESSES FEATURES IN LIQUID-GAS SYSTEMS}

A. Pavlenko

Doctor of Technical Sciences, Professor Department of Building Physics and Renewable Energy

Kielce University of Technology Tysiacholittia panstva Polskoho str., 7 , Kielce, Poland, 25-314

E-mail: am.pavlenko@i.ua

B. K u t n y i

$\mathrm{PhD}$, Associate Professor* E-mail: kytnuba@rambler.ru

N. A b d u I I a h

Postgraduate student*

*Department of heat and gas supply, ventilation and heat and power engineering Poltava National Technical Yuri Kondratyuk University Pershotravnevyi ave., 24, Poltava, Ukraine, 36011

\section{Introduction}

In many operating processes, gas-to-steam bubbles play a major technological role. As an example, we should mention the following technologies: degassing of water, distillation of petroleum products, cleaning of surfaces by cavitation, homogenization of fuel, mixing of colloidal solutions, foam formation in the food industry, etc. Modern technologies for the insulating materials production [1], desalination of sea water with the help of isobutane hydrate [2-4], and obtaining of natural gas hydrate [5, 6] for transportation and storage are also based on heat and mass transfer processes in the gas-liquid systems.

Generally, formation and existence of gas-to-steam bubbles are accompanied by intensive heat transfer, mass transfer and phase transition processes. The complexity of the "direct" observations (small bubble sizes, high velocity of processes) led to the widespread use of mathematical modeling research methods. Mathematical models allow identifying the most powerful factors and optimizing technological processes. Correctness of the mathematical models of gas-to-steam bubbles is determined by the accuracy of accounting all thermal and physical processes taking place in the liquid and gas.
Typically, the known methods for calculating this type of heat and mass transfer processes only approximately take into account the temperature regime of the liquid and the phase transition processes occurring around gas-to-steam bubbles. Taking into consideration the transition processes in the liquid will significantly improve the accuracy of calculations and extend the limits of such mathematical models' application. That is why studies in this field are extremely topical.

\section{Literature review and problem statement}

To improve the accuracy of simulating heat transfer processes in the gas-to-steam bubble, it is necessary to consider the heat transfer into the liquid medium. A number of authors take the liquid temperature to be constant: when calculating the materials swelling [1], when determining the thermodynamic characteristics of steam [7] and cavitation bubbles [8]. In [9], the liquid temperature is described by the exponential function that does not depend on time and the direction of the bubble wall's movement. Some authors [10] consider the liquid's heat transfer layer to be so thin that the 
curvature of the bubble's surface can be ignored. However, such assumptions are only possible for a very limited group of tasks. In [11] for cavitation and in [12] for steam bubbles, the analytical solution for the problem of non-stationary heat conductivity in a layer of liquid surrounding an oscillating bubble is suggested. As a result of the author's assumptions, the solution of this problem is obtained, where the liquid's heat transfer layer is equal to the radius of the bubble and does not depend on thermal and physical characteristics of the liquid. In [13], only heat conductivity in a liquid is taken into account, without considering phase transition processes. An overview of the above literature sources shows that phase transition processes in the liquid surrounding the gas-to-steam bubble are not sufficiently studied.

The temperature regime of gas inside the bubble can widely vary: from a temperature below the freezing point of the liquid during periods of the bubble's "growth" to a temperature higher than the boiling point of the liquid during the periods of the bubble's compression. Changing the phase state of the liquid causes significant change in heat and mass transfer processes at its boundary.

To expand the limits of the gas-to-steam bubble's mathematical modeling, it is necessary to consider phase transition processes of heat transfer in the liquid surrounding the gas-tosteam bubble. As a result, thermal and physical characteristics of the substance at the bubble's boundary can change considerably. The peculiarity of this task is movement of the bubble's wall, which velocity, at some moments, can reach several tens of meters per second.

\section{The aim and objectives of the study}

The aim of the present study was to design a mathematical model of heat transfer in the liquid surrounding the oscillating gas-to-steam bubble. Heat transfer processes in the liquid may be accompanied by a change in the aggregate state and in thermal and physical characteristics.

To achieve this aim, the following objectives were set:

- to take into account non-stationary processes of changes in the liquid aggregate state and in its thermal and physical characteristics in the mathematical model;

- to calculate phase transition processes in the liquid surrounding the gas-steam bubble using mathematical modeling;

- to estimate the temperature regime in the liquid under different initial conditions.

\section{A mathematical model of phase transition processes in the liquid}

To develop the mathematical model of heat transfer in the liquid, the following simplifying assumptions are applied:

- the boundary conditions of the second kind are prescribed near the bubble's surface;

- the gas-steam bubble has a spherical shape and is surrounded by an infinite amount of liquid;

- the bubble's center is not displaced relative to the liquid.

To determine the temperature in the column of liquid surrounding the gas-to-steam bubble, it is necessary to consider the process of heat transfer within the liquid. To calculate the heat transfer by means of heat conduction, the Fourier heat transfer equation is normally used, and con- vection can be considered by applying the efficient thermal conductivity factor.

Let us denote by " $x$ " the coordinate, where the bubble's radius is changing. To determine the unknown temperature on the surface of the bubble and in the column of liquid $\left(T_{(x, \tau)}\right)$, a nonlinear Fourier heat conductivity equation for a sphere can be used, with account of its walls mobility [9] and the action of sizable heat sources:

$$
\frac{\partial\left(\rho_{r} c_{r} T_{(x, \tau)}\right)}{\partial \tau}+\dot{x} \frac{\partial\left(\rho_{r} c_{r} T_{(x, \tau)}\right)}{\partial x}=\frac{1}{x^{2}} \frac{\partial}{\partial x}\left(\lambda_{r} x^{2} \frac{\partial T_{(x, \tau)}}{\partial x}\right)+q_{v(x, T)},
$$

where $\rho_{r}$ - liquid density, $\mathrm{kg} / \mathrm{m}^{3} ; c_{r}-$ its heat capacity, $\mathrm{J} /\left(\mathrm{kg}^{\circ} \mathrm{C}\right) ; \tau$ - time coordinate, sec; $\dot{x}$ - velocity of the bubble's radius change, $\mathrm{m} / \mathrm{sec} ; \lambda_{r}-$ efficient thermal conductivity factor of the liquid, $\mathrm{W} /\left(\mathrm{m}^{\circ} \mathrm{C}\right) ; q_{v}$ - capacity of sizable heat sources, $\mathrm{W} / \mathrm{m}^{3}$. As a result of heat transfer processes at the boundary of the bubble, the liquid can change its thermal and physical characteristics, so we will be solving the problem as a non-linear one. The use of heat sources makes the equation (1) heterogeneous.

Taking into account that the specific heat flow (q) near the surface of the bubble is known, we can write the boundary condition of the second kind:

$$
-\frac{\partial \lambda_{r} T_{(R, \tau)}}{\partial x}=q_{(R, \tau)} .
$$

Equation (2) takes into account the change in the thermal conductivity factor at the bubble's boundary, for example, in the case of the liquid's freezing.

In such a statement, the problem is convenient to solve by the method of finite elements. To describe the thermal conductivity in the liquid surrounding the bubble with radius $\mathrm{R}$, let us divide the liquid layer into a series of concentric membranes (i), Fig. 1. Let us set the mass distribution of each membrane:

$$
\begin{aligned}
& m_{r(2)}=2 K_{r} m_{r(1)}, \\
& m_{r(i)}=K_{r} m_{r(i-1)},
\end{aligned}
$$

where $m_{r(1)}-$ mass of the 1st (internal) layer's membrane, $\mathrm{kg} ; m_{r(i)}-$ mass of each subsequent membrane, kg; $K_{r}-$ proportionality factor. This factor allows to "compact" the elements mesh near the bubble's border and to "rarefy" it in the deeper layers of the liquid. The above factor is used to optimize calculations and its typical values are within $1.5-2$.

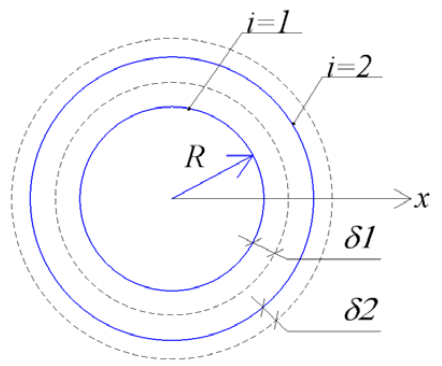

Fig. 1. Diagram of the liquid's division into a series of concentric membranes 
Now we shall determine the temperature on the first (internal) membrane's internal surface. To do this, we formulate the equation of the first membrane's thermal balance:

$$
Q_{A K}=Q_{1}+Q_{2}+Q_{\Phi},
$$

where $Q_{A K}-$ heat flow that accumulates and causes the temperature increase of the given membrane, $\mathrm{W} ; Q_{1}$ - heat flow from the surface of the bubble into the steam-gas medium, W; $Q_{2}$ - heat flow from the second layer of the liquid into the first one, $\mathrm{W} ; Q_{\Phi}$ - heat flow that causes an increase in the solid phase mass (e. g. ice), W. Let us reveal the value of these heat flows.

Heat flow, which is accumulated in the membrane and causes an increase in its temperature, can be determined by means of the known formula:

$$
Q_{A K}=m_{r(1)} c_{r(1)} \frac{d T_{(R, \tau)}}{d \tau}
$$

where $c_{r(1)}$ - heat capacity of the first membrane's medi$\mathrm{um}, \mathrm{J} /\left(\mathrm{kg}^{\circ} \mathrm{C}\right)$. We will write the heat flow from the bubble's surface into its steam-gas medium as a boundary condition of the 2 nd kind. Heat removal will reduce the membrane's temperature, therefore this heat flow is negative:

$$
Q_{1}=-F_{R} q_{(R, \tau)}
$$

where $F_{R}$ - heat transfer area, $\mathrm{m}^{2}$.

The heat flow from the outer membrane to the internal one is more convenient to consider within a single layer, for which at the given moment $\lambda_{r(i)}=$ const:

$$
Q_{2}=\frac{4 \pi \lambda_{r(1)}\left(T_{(R+\delta 1, \tau)}-T_{(R, \tau)}\right)}{\frac{1}{r_{(1)}}-\frac{1}{r_{(1)}+\delta 1}} .
$$

The increase in the solid phase mass requires removal of heat energy from the designed membrane and, therefore, is an additional source of the heat energy

$$
Q_{\Phi}=r_{\Phi} \frac{d m_{\Phi(1)}}{d \tau}
$$

where $r_{\Phi}$ - phase transition heat, $\mathrm{J} / \mathrm{kg} ; m_{\Phi(1)}-$ solid phase mass of the 1st (internal) layer's membrane, kg.

Taking into account the values of individual heat flows, formulas (5)-(8), for the internal membrane can be written as a general differential equation of the thermal balance:

$$
\begin{aligned}
& m_{r(1)} c_{r(1)} \frac{d T_{(R, \tau)}}{d \tau}= \\
& =-F_{R} q_{(R, \tau)}+\frac{4 \pi \lambda_{r(1)}\left(T_{(R+\delta 1, \tau)}-T_{(R, \tau)}\right)}{\frac{1}{r_{(1)}}-\frac{1}{r_{(1)}+\delta 1}}+r_{\Phi} \frac{d m_{\Phi(1)}}{d \tau} .
\end{aligned}
$$

The last component of the equation (9) only exists under certain conditions, which need to be specified separately. Within a single iteration step, the membrane's radius remains constant and, for convenience in calculations, it can be designated as:

$$
K_{1}=\frac{\lambda_{r(1)}}{\frac{1}{r_{(1)}}-\frac{1}{r_{(1)}+\delta 1}}=\frac{\lambda_{r(1)}}{\frac{1}{R}-\frac{1}{R+\delta 1}}
$$

Now, the differential equation determining the temperature on the inner layer's surface of the bubble is written as:

$$
\begin{aligned}
& \frac{d T_{(R, \tau)}}{d \tau}= \\
& =\frac{4 \pi}{m_{r(1)} c_{r(1)}}\left(-R^{2} q+K_{1}\left(T_{(R+\delta 1, \tau)}-T_{(R, \tau)}\right)+r_{\Phi} \frac{d m_{\Phi(1)}}{d \tau}\right) .
\end{aligned}
$$

In the absence of mass transfer processes, the mass of the 1st layer remains unchanged, therefore:

$$
m_{r(1)}=\frac{4}{3} \pi \rho_{r 1}\left[(R+\delta 1)^{3}-R^{3}\right]=\text { const. }
$$

Where the outer radius of the 1 st membrane can be determined:

$$
R+\delta 1=\sqrt[3]{r_{R}^{3}+\frac{3 m_{r(1)}}{4 \pi \rho_{r 1}}}=\sqrt[3]{R^{3}+\frac{3 m_{r(1)}}{4 \pi \rho_{r 1}}} .
$$

Similarly, differential equations for all subsequent membranes can be written as:

$$
\begin{aligned}
& m_{r(i)} c_{r(i)} \frac{d T_{(x, \tau)}}{d \tau}=\frac{4 \pi \lambda_{r}\left(T_{(i-1)}-T_{(i)}\right)}{\frac{1}{r_{(i-1)}}-\frac{1}{r_{(i)}}}- \\
& -\frac{4 \pi \lambda_{r}\left(T_{(i)}-T_{(i+1)}\right)}{\frac{1}{r_{(i)}}-\frac{1}{r_{(i+1)}}}+r_{\Phi} \frac{d m_{\Phi(i)}}{d \tau} .
\end{aligned}
$$

With account of the problem's non-linearity, the temperature difference between the neighboring layers is more convenient to replace with the temperature difference between the middle of the layer and its edges (boundaries):

$\frac{d T_{\left(r_{i}, \tau\right)}}{d \tau}=$

$=\frac{4 \pi}{m_{r(i)} c_{r(i)}}\left(K_{3}\left(T_{\left(r_{i}-\delta i, \tau\right)}-T_{\left(r_{i}, \tau\right)}\right)-K_{1}\left(T_{\left(r_{i}, \tau\right)}-T_{\left(r_{i}+\delta i, \tau\right)}\right)\right)+\frac{q_{v(i)}}{\rho_{r(i)} c_{r(i)}}$,

where $T_{\left(r_{i}+\delta i, \tau\right)}$ - temperature on the outer boundary of the $i$-th membrane, ${ }^{\circ} \mathrm{C} ; T_{\left(r_{i}-\delta i, \tau\right)}$ - temperature on the internal boundary of the $i$-th membrane, ${ }^{\circ} \mathrm{C}$. At every iteration step, these temperatures are determined with account of the thickness and thermal conductivity of the adjacent layers.

The temperature at the outer boundary of the $i$-th membrane is:

$$
T_{\left(r_{i}+\delta i, \tau\right)}=\frac{K_{1} T_{i}+K_{2} T_{i+1}}{K_{1}+K_{2}} .
$$

The temperature at its internal boundary:

$$
T_{\left(r_{i}-\delta i, \tau\right)}=\frac{K_{4} T_{i-1}+K_{3} T_{i}}{K_{4}+K_{3}} .
$$


Factors $K 1, K 2, K 3, K 4$ are determined by the following formulas:

$$
\begin{gathered}
K_{1}=\frac{\lambda_{r(i)}}{\frac{1}{r_{(i)}}-\frac{1}{r_{(i)}+\delta_{(i)}}}, \\
K_{2}=\frac{\lambda_{r(i+1)}}{\frac{1}{r_{(i)}+\delta_{i}}-\frac{1}{r_{(i+1)}}}, \\
K_{3}=\frac{\lambda_{r(i)}}{\frac{1}{r_{(i)}-\delta_{(i)}}-\frac{1}{r_{(i)}}}, \\
K_{4}=\frac{\lambda_{r(i-1)}}{\frac{1}{r_{(i-1)}}-\frac{1}{r_{(i)}-\delta_{i}}} .
\end{gathered}
$$

Considering the membranes volumes, their radii can be determined:

$$
\begin{aligned}
& V_{(i)}-V_{(i-1)}=\frac{4 \pi}{3}\left(r_{(i)}^{3}-r_{(i-1)}^{3}\right)= \\
& =\frac{1}{2} V_{(i-1)}+\frac{1}{2} V_{(i)}=\frac{1}{2}\left(\frac{m_{r(i-1)}}{\rho_{r(i-1)}}+\frac{m_{r(i)}}{\rho_{r(i)}}\right) .
\end{aligned}
$$

Based on (21), the average radius of the $i$-th membrane is found by the formula:

$$
r_{(i)}=\sqrt[3]{r_{(i-1)}^{3}+\frac{3}{8 \pi}\left(\frac{m_{r(i-1)}}{\rho_{r(i-1)}}+\frac{m_{r(i)}}{\rho_{r(i)}}\right)}
$$

Since the mass of the first membrane is not divisible in half, the 2nd membrane's radius is determined by the following formula:

$$
r_{(2)}=\sqrt[3]{R^{3}+\frac{3}{4 \pi} \frac{m_{r(1)}}{\rho_{r 1}}+\frac{3}{8 \pi} \frac{m_{r(2)}}{\rho_{r 2}}}
$$

Considering that the masses of the outer and the internal membrane halves are equal, the radii can also be determined by the analogous formulas.

The outer radius of the $i$-th membrane is:

$$
r_{(i)}+\delta_{i}=\sqrt[3]{r_{(i)}^{3}+\frac{3 m_{r(i)}}{8 \pi \rho_{r(i)}}}
$$

The internal radius of the $i$-th membrane is:

$$
r_{(i)}-\delta_{i}=\sqrt[3]{r_{(i)}^{3}-\frac{3 m_{r(i)}}{8 \pi \rho_{r(i)}}}
$$

At particular moments, in different membranes, favorable conditions to perform phase transition can be created. In this case, it is necessary to consider three components: temperature regime, mass of the solid and liquid phases, the effect of sizable heat sources. The conditions of the first-kind phase transition consist of the two parts: the condition of icing and the condition of ice melting.

The condition for icing is:

$$
T_{\left(r_{i}, \tau\right)} \leq T_{\Phi} \text { and } m_{\Lambda\left(r_{i}, \tau\right)}<m_{\left(r_{i}, \tau\right)} \text { and } Q_{\Phi\left(r_{i}, \tau\right)}>0,
$$

where $T_{\Phi}$ - phase transition temperature, ${ }^{\circ} \mathrm{C} ; m_{\Lambda\left(r_{i}, \tau\right)}-$ mass of the solid phase in the $i$-th layer at any moment, kg; $Q_{\Phi\left(r_{i}, \tau\right)}$ - heat flow, which is deduced from the $i$-th layer to perform the phase transition, $\mathrm{W}$.

The condition for ice melting is:

$$
T_{\left(r_{i}, \tau\right)} \geq T_{\Phi} \text { and } m_{\Lambda\left(r_{i}, \tau\right)}>0 \text { and } Q_{\Phi\left(r_{i}, \tau\right)}<0 .
$$

If the $i$-th layer undergoes a phase transition, then the temperature of this layer does not change, and

$$
\frac{d T_{\left(r_{i}, \tau\right)}}{d \tau}=0 .
$$

In this case, the power of sizable heat sources can be determined by the formula:

$$
0=\frac{4 \pi}{m_{r(i)} c_{r(i)}}\left(K_{3}\left(T_{\left(r_{i}-\delta i, \tau\right)}-T_{\left(r_{i}, \tau\right)}\right)-K_{1}\left(T_{\left(r_{i}, \tau\right)}-T_{\left(r_{i}+\delta i, \tau\right)}\right)\right)+\frac{q_{v(i)}}{\rho_{r(i)} c_{r(i)}} .
$$

Whence, after simplification, we obtain

$$
q_{v(i)}=\frac{4 \pi}{V_{r(i)}}\left(K_{3}\left(T_{\left(r_{i}, \tau\right)}-T_{\left(r_{i}-\delta i, \tau\right)}\right)-K_{1}\left(T_{\left(r_{i}+\delta i, \tau\right)}-T_{\left(r_{i}, \tau\right)}\right)\right) .
$$

Similarly, the power of sizable heat sources for the 1-st membrane can be found as follows:

$$
q_{v(1)}=\frac{4 \pi}{V_{r(1)}}\left(R^{2} q-K_{1}\left(T_{(R+\delta 1, \tau)}-T_{(R, \tau)}\right)\right) .
$$

The sizable heat sources' intensity being known, the change of the solid phase mass can be determined.

$$
m_{\Lambda\left(r_{i}, \tau+\Delta \tau\right)}=m_{\Lambda\left(r_{i}, \tau\right)}+\frac{q_{v(i)} \cdot \Delta \tau \cdot V_{r(i)}}{r_{\Phi}} .
$$

In the case of a phase transition, a change in the thermal and physical properties will take place in the $i$-th layer of the liquid. Therefore, at each iteration step, the thermal and physical characteristics of the layers need to be specified according to the formulas:

- density

$$
\rho_{r(i)}=\frac{\rho_{\Lambda(i)} m_{\Lambda(i)}+\rho_{w(i)}\left(m_{(i)}-m_{\Lambda(i)}\right)}{m_{(i)}} ;
$$

- thermal conductivity

$$
\lambda_{r(i)}=\frac{\lambda_{\Lambda(i)} m_{\Lambda(i)}+\lambda_{w(i)}\left(m_{(i)}-m_{\Lambda(i)}\right)}{m_{(i)}} ;
$$

- heat capacity

$$
c_{r(i)}=\frac{c_{\Lambda(i)} m_{\Lambda(i)}+c_{w(i)}\left(m_{(i)}-m_{\Lambda(i)}\right)}{m_{(i)}} .
$$


The density change, with the constant mass, will change the size of the layers, which may complicate the calculation process. Taking into account that the density and heat capacity are used as the product, the density change can be replaced by the equivalent change in heat capacity. With account of the density correction, the $i$-th layer's heat capacity is determined by the formula:

$$
c_{r(i)}=\frac{\rho_{r(i)}}{\rho_{w}} \times \frac{c_{\Lambda(i)} m_{\Lambda(i)}+c_{w(i)}\left(m_{(i)}-m_{\Lambda(i)}\right)}{m_{(i)}},
$$

where $\rho_{w}$ - liquid density at the initial temperature, $\mathrm{kg} / \mathrm{m}^{3}$. In this case, the density of all layers is given equal to $\rho_{r(i)}=\rho_{w}$.

To solve the system of differential equations (11) and (14), the Runge-Kutta 4-th order method is applied [14]. In order to assess the adequacy of the developed mathematical model, a computer software has been developed and a number of mathematical experiments have been performed. The results of the calculation are reflected in the experiments No. 1-6.

\section{Results of the phase transition studies in the liquid}

Source data. Let us consider the heat and mass transfer processes in the liquid at the initial stage of the barbotage introducing of bubbles into gas into water [15]. With regard to technology, such processes are characteristic of carbonization [16], formation of isobutane hydrate [17] and other hydrates [18-20]. Duration of the estimated time interval is $3-6 \mu$ s (microseconds). The time step is $0.005-0.01 \mathrm{~ns}$, the specific heat flow near the bubble's surface (boundary condition of the 2 nd kind) is $1 \mathrm{MW} / \mathrm{m}^{2}$. The initial diameter of the bubble is $0.1 \mathrm{~mm}$, the initial water temperature is $+0.5^{\circ} \mathrm{C}$. The estimated layers are 12 in number, $\mathrm{Kr}$ factor equals 1.5.

The initial values of heat conductivity, density and heat capacity of water are taken at the temperature of $+0.5^{\circ} \mathrm{C}$. The heat of the water-to-ice phase transition is $335 \mathrm{~kJ} / \mathrm{kg}$. The temperature of the steam-gas medium of the real bubble can vary within a pretty wide range. To study the phase transition processes in water, the bubble with the steam-gas medium temperature below the phase transition temperature will be called "cold". The bubble with the steam-gas medium temperature higher than the phase transition temperature will be called "hot".

Experiment No. 1. Let us consider a bubble in the water formed during the barbotage gas throttling through the narrow nozzle. Due to the Joule-Thompson effect, the gas temperature inside the bubble is lower than the temperature of the surrounding liquid. Considering the gas pressure inside the bubble equal to the pressure of the water (with account of the surface tension forces), we will take the velocity of the bubble walls equal to $0 \mathrm{~m} / \mathrm{sec}$. The results of the temperature regime calculation for the liquid surrounding the "cold" bubble, are shown in Fig. 2.

Experiment No. 2. If the gas pressure in the bubble exceeds the pressure of the liquid, the bubble expands. Let us consider the processes in the liquid during the "cold" bubble expansion with the wall movement velocity of $10 \mathrm{~m} / \mathrm{sec}$. The calculation results are shown in Fig. 3.

Experiment No. 3. In the process of oscillation, the phase of the bubble's expansion is replaced with the phase of compression. Let us consider the processes in the liquid during the period of the "cold" gas bubble compression with the wall movement velocity of $-10 \mathrm{~m} / \mathrm{sec}$. The calculation results are shown in Fig. 4.

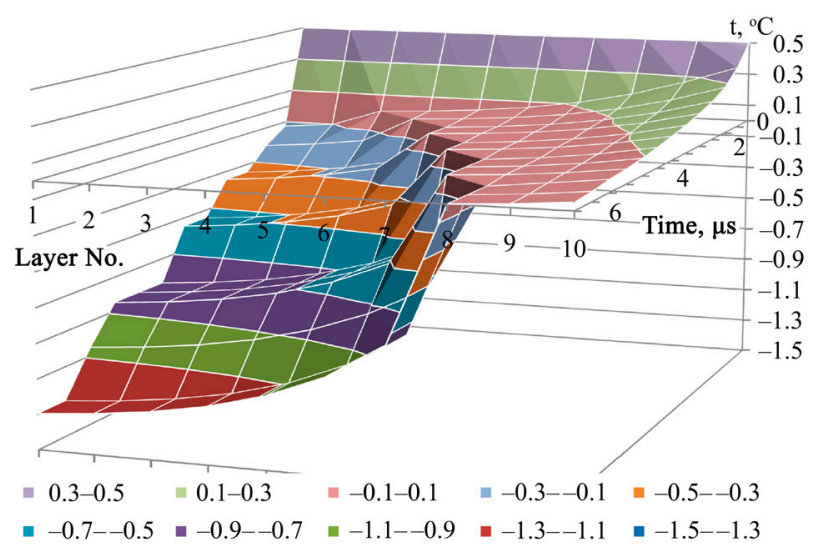

Fig. 2. Diagram of temperature fields in the water surrounding a stationary wall "cold" bubble $(\dot{R}=0 \mathrm{~m} / \mathrm{sec})$

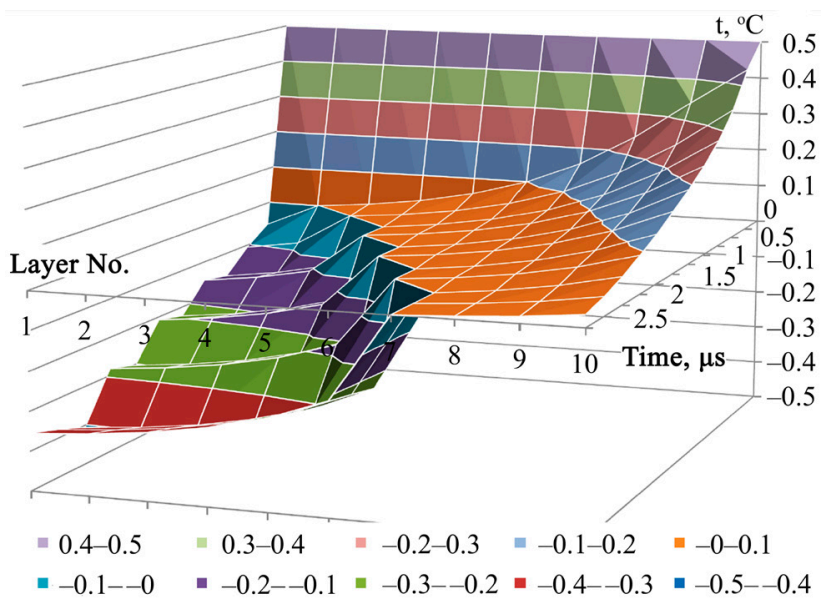

Fig. 3. Diagram of temperature fields in the water surrounding a "cold" bubble expanding with the velocity of $\dot{R}=10 \mathrm{~m} / \mathrm{sec}$

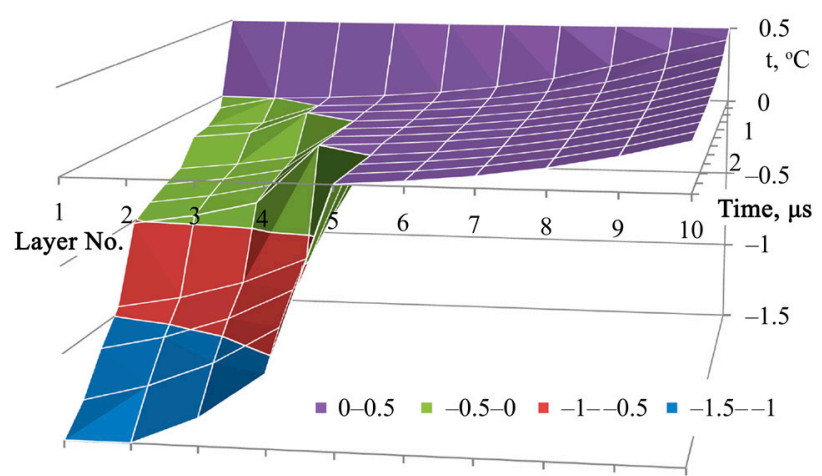

Fig. 4. Diagram of temperature fields in the water surrounding a "cold" bubble compressing with the velocity of $\dot{R}=10 \mathrm{~m} / \mathrm{sec}$

During the period of the bubble compression, the gas temperature in it increases and favorable conditions are created for melting of the ice crust formed at the previous stages of the bubble's oscillation. As time passes, the movement of the bubble's wall slows down, and the process of expansion 
starts in the conditions of the high gas temperature. The next series of calculations was performed to study the phase transition processes around the "hot" bubble.

Experiment No. 4. A bubble with "hot" gas is immobile and is surrounded with an ice crust. Let us consider the process of ice melting around the bubble. Based on preliminary calculations, the initial ice temperature will be taken at $-0.5^{\circ} \mathrm{C}$.

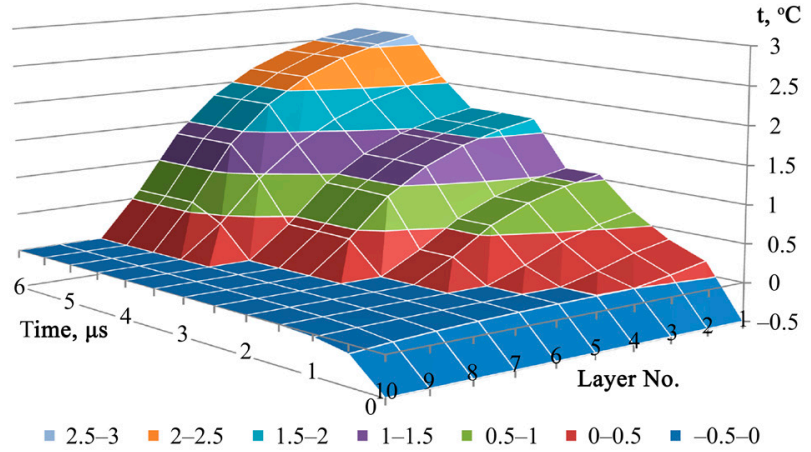

Fig. 5. Diagram of temperature fields in the water-ice system surrounding the immobile "hot" bubble $(\dot{R}=0 \mathrm{~m} / \mathrm{sec})$

Experiment No. 5. The "hot" bubble expands with the velocity of $10 \mathrm{~m} / \mathrm{sec}$. The calculation results are shown in Fig. 6.

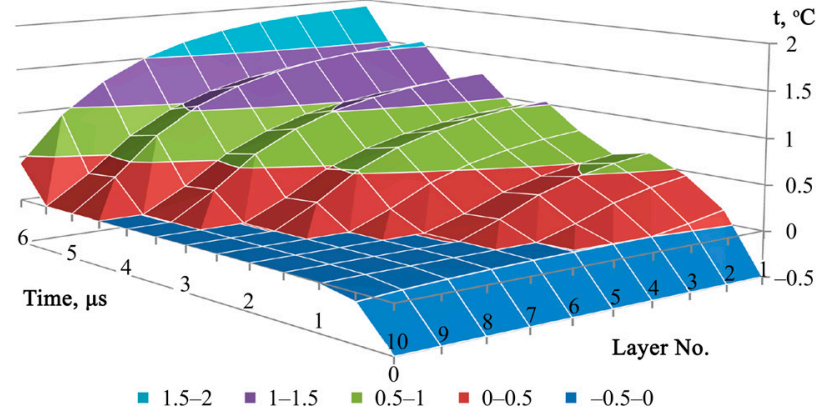

Fig. 6. Diagram of temperature fields in the water-ice system surrounding the "hot" bubble that is compressing with the velocity of $\dot{R}=10 \mathrm{~m} / \mathrm{sec}$

Experiment No. 6. Let us consider the ice melting while a "hot" bubble is compressing with the velocity of $10 \mathrm{~m} / \mathrm{sec}$ (Fig. 7). The initial temperature of ice was taken at $-0.5^{\circ} \mathrm{C}$.

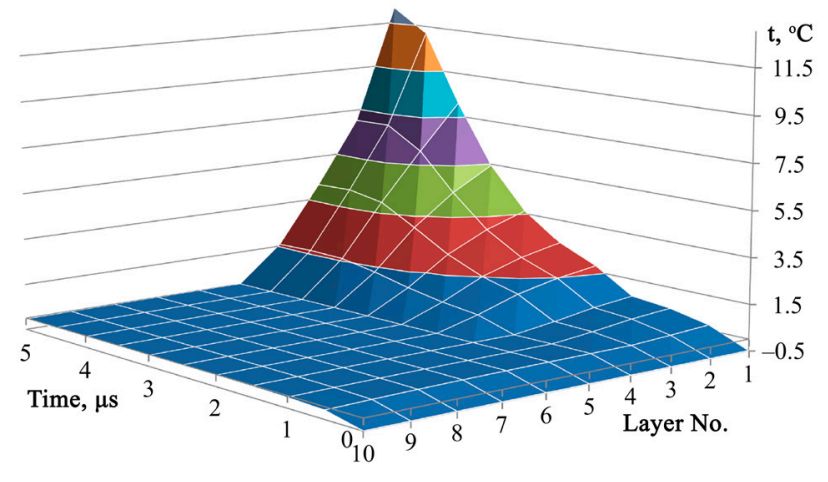

| $11.5-13=9.5-11.5$ | $7.5-9.5$ | 5.5-7.5 | $3.5-5.5=1.5-3.5=-0.5-1.5$

Fig. 7. Diagram of temperature fields in the water-ice system surrounding the "hot" bubble that is compressing with the velocity of $\dot{R}=-10 \mathrm{~m} / \mathrm{sec}$

\section{Discussion of the results of the mathematical modeling} of phase transition processes in the liquid

The upper part of Fig. 2 shows a relatively rapid cooling of the liquid to the temperatures close to the phase transition temperature $\left(0{ }^{\circ} \mathrm{C}\right)$. The phase transition itself is observed as an almost horizontal platform approximately in the center of the diagram. The left side of the diagram illustrates the process of ice cooling.

The stepped nature of the ice temperature is explained by a small number of the designed layers (12 pcs.). The freezing depth has made 5 layers of the liquid around the bubble for $2.0 \mathrm{~ms}$.

As it is seen in Fig. 3, the freezing depth has made 6 layers of liquid for $2.0 \mathrm{~ms}$.

Comparison of the frozen layers masses in Experiments 1 and 2 shows that when the bubble expands the liquid freezing is approximately 1.6 times faster. This is due to an increase of the heat transfer surface area when the bubble size is expanding. In the left side of the diagram, the ice temperature is bearing a jagged nature. A slight rise in temperature is observed due to the reduction of thickness and the membranes' thermal resistance in the process of the bubble expansion. In general, reducing the solid phase membranes' thickness leads to the fact that the surface temperature of the bubble is closer to the phase transition temperature than it was in experiment No. 1.

The results of the "cold" bubble compression calculation, presented in Fig. 4, demonstrate that in this case, the freezing of the liquid significantly slows down. Namely, the ice thickness was only $60 \%$ of the variant with an immobile bubble wall. This is explained by a reduction of the heat transfer surface area. Due to the freezing layers' thickness increase, the thermal resistance grows and the internal surface temperature of the bubble reduces more rapidly than in experiments 1 and 2 .

The results of the immobile "hot" bubble calculation (Fig. 5) show a relatively rapid initial warming of the ice layers to the phase transition temperature. Comparing the results with Experiment No.1, it can be noted that the melting process occurs at almost the same velocity as that of the freezing process. This is facilitated by the boundary condition of the 2nd kind. Almost four times less than the thermal conductivity of water in comparison with that of ice, causes more intense heating of the interphase liquid-gas surface.

In experiment No. 5 , as in experiment No. 2, ice melting is accelerated due to the heat transfer surface expansion. Also, a slower wall temperature rise occurs, and the specific "pulverulent" form of the temperature field is caused by a gradual reduction of the membranes' thickness.

The results of calculating the "hot" bubble compression (Fig. 7) show a significant deceleration of the ice melting process compared with the previous calculation. The temperature of water's internal layers grows much more rapidly than in Experiments 4 and 5. This is facilitated by both the water layers thickness growth when compressing the bubble, and the much less thermal conductivity of water compared with that of ice (approximately 4 times). Reduction in the amount of the melted ice is due to the surface area reduction of the heat transfer, and as a consequence, reduction in the total amount of heat that is brought to the interphase surface of the bubble.

Thus, with the help of mathematical modeling, the distribution of temperature fields in the liquid in the conditions 
of the phase transition processes and the bubble size change (Experiments No.1-6) was obtained. The study performed demonstrates that the method of finite elements (3)-(34) used for the mathematical model of non-stationary heat transfer in the liquid (1)-(2) surrounding the oscillating gas-tosteam bubble correctly displays the physical processes.

It takes into account the change in the thermal and physical characteristics of the liquid (31)-(34), the change in the bubble size (12), (22)-(25), the heat transfer processes at its boundary (9), and the phase transition processes in the liquid column (26)-(30). The designed mathematical model can be used to estimate the thermodynamic parameters of a two-phase liquid in various technological processes.

The suggested calculation technique can be used to determine the thermal and physical characteristics of liquid and steam in various technological processes associated with gases dissolution in liquid, foam hardening and gas hydrates formation.

\section{Conclusions}

1. A mathematical model of the non-stationary thermal conductivity of the oscillating bubble wall, which takes into account the change in the aggregate state as well as thermal and physical characteristics of the substance, has been developed. It is demonstrated that when applying the finite elements, method, it is a system of nonlinear differential equations of the 1st order. Consideration of the above features in the mathematical model allows obtaining the values of the liquid and solid phases temperatures at any specific time when changing the bubble's size, changing the direction of the heat flow at its boundary.

2 . To analyze the correctness of the mathematical modeling of transient processes in a liquid, a series of assessment calculations (experiments) has been performed. They were aimed at testing the reproduction of various thermodynamic conditions and gas-to-steam bubble modes by means of the mathematical model: heating and cooling together with the phase transition processes, compression and expansion. A diagram of temperature fields in the substance surrounding the gas-to-steam bubble was constructed for each experiment.

3 . The results of the calculation for an immobile $0.1 \mathrm{~mm}$ diameter bubble with a boundary condition of the 2nd kind showed that the icing and ice melting velocities are almost equal, but the temperature on the interphase gas-water surface is approximately four times exceeding the temperature of the gas-ice surface that complies to the ratio of the thermal conductivity of water and ice. The temperature in the liquid-ice phase transition zone is practically constant.

Comparison of the frozen layers masses shows that when the bubble is expanding, the liquid freezing and the ice melting are going more than 1.6 times faster than in the immobile bubble. When compressing the bubble, the thickness of the ice formed or melted is approximately 1.7 times smaller than that of the immobile bubble.

The analysis of the obtained results has demonstrated that they are predictable and completely correspond to the physicists' ideas of the heat transfer and phase transition processes flow in the liquid.

References

1. Pavlenko, A. M. Regularities of Boiling-Up of Emulsified Liquids [Text] / A. M. Pavlenko, B. I. Basok // Heat Transfer Research. 2005. - Vol. 36, Issue 5. - P. 419-424. doi: 10.1615/heattransres.v36.i5.90

2. Yakushev, V. S. Sovremennoe sostoyanie gazogidratnyh tekhnologiy [Text] / V. S. Yakushev, V. G. Kvon, Yu. A. Gerasimov, V. A. Istomin. - Moscow: OOO «IRTS Gazprom», 2008. -88 p.

3. Takeya, S. Self-preservation effect and dissociation rates of CH4 hydrate [Text] / S. Takeya, T. Ebinuma, T. Uchida, J. Nagao, H. Narita // Journal of Crystal Growth. - 2002. - Vol. 237-239. - P. 379-382. doi: 10.1016/s0022-0248(01)01946-7

4. Stem, L. A. Temperature, pressure, and compositional effects on anomalous or "self" preservation of gas hydrates [Text] / L. A. Stem, S. Circone, S. H. Kirby, W. B. Durham // Canadian Journal of Physics. - 2003. - Vol. 81, Issue 1-2. - P. 271-283. doi: 10.1139/p03-018

5. Behkish, A. Novel correlations for gas holdup in large-scale slurry bubble column reactors operating under elevated pressures and temperatures [Text] / A. Behkish, R. Lemoine, R. Oukaci, B. I. Morsi // Chemical Engineering Journal. - 2006. - Vol. 115, Issue 3. P. 157-171. doi: 10.1016/j.cej.2005.10.006

6. Hashemi, S. Dynamic Simulation of Gas Hydrate Formation in an Agitated Three-Phase Slurry Reactor [Text] / S. Hashemi, A. Macchi, P. Servio // The 12th International Conference on Fluidization - New Horizons in Fluidization Engineering. - 2007. - P. 329-336.

7. Shagapov, V. Sh. K teoryi rosta parovyh puzyr'kov v metastabil'noy zhidkosti [Text] / V. Sh. Shagapov, V. V. Koledin // Teplofizika vysokih temperatur. - 2013. - Vol. 51, Issue 4. - P. 543-551. doi: 10.7868/s0040364413040212

8. Veretel'nik, T. I. Matematicheskoe modelirovanie kavitatsionnogo potoka zhidkosti v himiko-tekhnologicheskoy sisteme [Text] / T. I. Veretel'nik, Yu. N. Difuchin // Visnyk ChDTU. - 2008. - Issue 3. - P. 82-85.

9. Aktershev, S. P. Modelirovanie vskipaniya metastabil'noy zhidkosti pri nalichii frontov ispareniya [Text] / S. P. Aktershev, V. V. Ovchinnikov // Sovremennaya nauka: issledovaniya, idei, rezul'taty, tekhnologi. - 2013. - Issue 1. - P. 77-82.

10. Nigmatulin, R. I. Dinamika i teplomassoobmen parogazovyh puzyr'kov s zhidkost'yu [Text] / R. I. Nigmatulin, N. S. Habeev // Nekotorye voprosy mekhaniki sploshnoy sredy. - Moscow: In-t mekhaniki MGU, 1978. - P. 229-243.

11. Kulinchenko, V. R. Peredumovy stvorennia matematychnoi modeli - osnovni polozhennia i rivniannia rukhu Releia [Text] / V. R. Kulinchenko, V. L. Zavialov, T. H. Mysiura // Naukovi pratsi Natsionalnoho universytetu kharchovykh tekhnolohyi. - 2007. Issue 22. - P. 36-41.

12. Dolinskiy, A. A. Teoreticheskoe obosnovanie printsipa diskretno-impul'snogo vvoda energyi. Model' dinamiki odinochnogo parovogo puzyr'ka [Text] / A. A. Dolinskiy, G. K. Ivanitskiy // Prom. teplotekhnika. - 1995. - Vol. 17, Issue 5. - P. 3-28.

13. Pavlenko, A. M. Kinetics of Water Evaporation from Emulsions [Text] / A. M. Pavlenko, B. I. Basok // Heat Transfer Research. 2005. - Vol. 36, Issue 5. - P. 425-430. doi: 10.1615/heattransres.v36.i5.100

14. Butcher, J. C. Numerical Methods for Ordinary Differential Equations [Text] / J. C. Butcher. - New York: John Wiley \& Sons, 2008. - 482 p. doi: 10.1002/9780470753767 
15. Kushnir, S. V. Barbotazhni khimichni efekty: yikh vydy, mekhanizmy vynyknennia ta heokhimichni proiavy [Text] / S. V. Kushnir, M. V. Kost, R. P. Kozak // Nakovo-tekhnichni visti. - 2016. - Issue 3 (20). - P. 30-47.

16. Ermolaeva, G. A. Tekhnologiya i oborudovanie proizvodstva piva i bezalkogol'nyh napitkov [Text]: ucheb. / G. A. Ermolaeva, P. A. Kolcheva. - Moscow: IRPO; Izd. tsentr «Akademiya», 2000. - 416 p.

17. Mosin, O. V. Fiziko-himicheskie osnovy opresneniya morskoy vody [Text] / O. V. Mosin // Soznanie i fizicheskaya real'nost'. 2012. - Issue 1. - P. 19-30.

18. Semenov, M. E. Sintez gidratov gazov laboratornyh usloviyah [Text]: XVII mezhdunar. nauch.-prakt. konf / M. E. Semenov, E. Yu. Shits // Tekhnicheskie nauki - ot teoryi k praktike. - Novosibirsk: SibAK, 2013. - P. 55-61.

19. Okutani, K. Surfactant effects on hydrate formation in an unstirred gas/liquid system: An experimental study using methane and sodium alkyl sulfates [Text] / K. Okutani, Y. Kuwabara, Y. H. Mori // Chemical Engineering Science. - 2008. - Vol. 63, Issue 1. P. 183-194. doi: 10.1016/j.ces.2007.09.012

20. Mel'nikov, V. P. Relaksatsionnyy YAMR-analiz fazovyh prevrashcheniy vody v dispersnoy sisteme voda/gidrat freona-12/ uglevodorod pri dissotsiatsyi gidrata [Text] / V. P. Mel'nikov, L. C. Podenko, A. N. Nesterov, A. M. Reshetnikov // DAN. - 2010. Vol. 433, Issue 1. - P. 59-61.

\begin{tabular}{|c|}
\hline 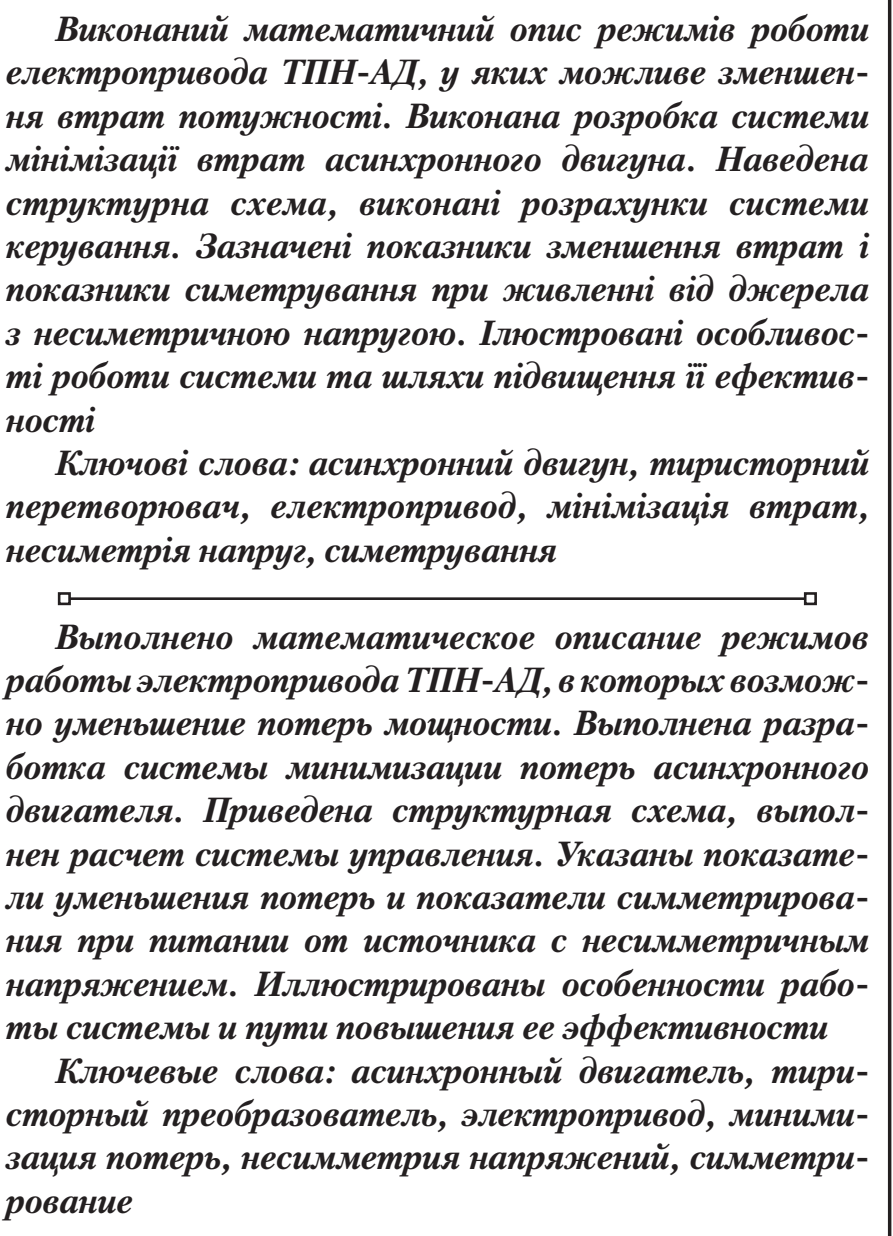 \\
\hline
\end{tabular}
електропривода ТІН-АД, у яких моэсливе змениення втрат потужності. Виконана розробка системи мінімізачї втрат асинхронного двигуна. Наведена структурна схема, виконані розрахунки системи керування. Зазначені показники зменшення втрат показники симетрування при живленні від джерела 3 несиметричною напругою. Ілюстровані особливості роботи системи та иляхи підвищення ї̈ ефективocmi

Ключові слова: асинхронний двигун, тиристорний перетворювач, електропривод, мінімізачія втрат, несиметрія напруг, симетрування

Выполнено математическое описание режимов работы электропривода ТПН-АД, в которых возмождвигателя. Приведена структурная схема, выполнен расчет системы управления. Указаны показатели уменьшения потерь и показатели симметрирования при питании от источника с несимметричным напряжением. Иллюстрированы особенности рабоКлючевые слова: асинхронный двигатель, тиристорный преобразователь, электропривод, минимизащия потерь, несимметрия напряжении, симметри-

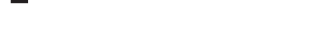

\section{Introduction}

A trend to building-up mass production of controlled electric drives (ED) is observed in the current world practice. By the beginning of the 2000s, leading electrical companies had stopped or significantly reduced production of direct current ED [1]. According to the data of economically developed countries, ED with asynchronous motors (AM), mainly with a squirrel-cage rotor, account for $80 \%$ to $90 \%$ of the total amount of electric power consumed by
ED. This is due to their relatively low cost, less need for scarce materials in comparison with electric motors of other types, cost effectiveness, simplicity, and reliability of operation. As applied to asynchronous motors, two systems of ED are widely used: ED with thyristor voltage converters (TVC) and ED with frequency converters (FC). Advantages and disadvantages of both ED systems are known. The use of ED of one or another system is determined by the technical and economic requirements of the driven mechanisms to the ED. 